\title{
Use of SDHB immunohistochemistry to identify germline mutations of SDH genes
}

\author{
AJ Gill \\ From Familial Aspects of Cancer 2011 Research and Practice: A combined meeting of kConFab, Australian \\ Breast Cancer Family Study, Australian Colorectal Cancer Family Study, Australian Ovarian Cancer Study, \\ Family Cancer Clinics of Australia and New Zealand and kConFab \\ Kingscliff, Australia. 23-26 August 2011
}

Pheochromocytomas and paragangliomas occur sporadically but are commonly associated with the von Hippel Lindau (VHL) syndrome, multiple endocrine neoplasia type 2 (MEN2), neurofibromatosis type 1 (NF1) and germline mutations of succinate dehydrogenase $\mathrm{B}$ (SDHB), C (SDHC) or D (SDHD). It is therefore recommended that genetic testing be considered if not performed in all cases of even apparently sporadic pheochromocytomas or paragangliomas. Recently it has been demonstrated that immunohistochemistry (IHC) for SDHB is negative in all SDH mutated paragangliomas regardless of whether the $B, C$ or $D$ subunit is involved [1,2]. Furthermore some clearly syndromic paragangliomas without known genetic mutation (including but not limited to those which occur in the Carney Triad) are identified by negative staining for SDHB [3].

Although historically the renal tumours occurring in the setting of SDHB mutation were usually classified as conventional clear cell carcinoma or oncocytoma, they actually display a unique morphology (unrecognized until know) and which can be confirmed by immunohistochemistry.

The GISTs occurring in SDH mutation and Carney Triad are also unique and demonstrate quite a different morphology, natural history and molecular pathogenesis compared to other GISTs occurring in adults (but similar to most GISTs occurring in childhood). We call this unique subtype of GIST the type 2 GIST. Briefly type 2 GISTs arise in the stomach, show an epithelioid morphology, are often multifocal, commonly show lymph node metastasis, are wild type for KIT and PDGFR, have

Correspondence: affgill@med.usyd.edu.au

Royal North Shore Hospital, Australia a prognosis not predicted by size and mitotic rate, never respond to imatinib but demonstrate an indolent growth despite the presence of frequent metastases [3,5].

We recommend that all paragangliomas, GISTs which potentially display type 2 morphological or clinical features and renal carcinomas which display the unique morphology we described should undergo immunohistochemistry for SDHB. Negative staining for SDHB indicates an abnormality of the mitochondrial complex 2 and is an absolute indication for formal genetic testing. We perform and interpret SDHB immunohistochemistry of archived formalin fixed paraffin embedded tissue in a manner analogous to MSI testing in colon cancer. In the setting of paraganglioma or renal carcinoma negative staining almost always indicates germline SDHB, SDHC or SDHD mutation (greater than 90\% chance) but may indicate Carney Triad. In the setting of GIST, Carney Triad is more likely, but SDHB, SDHC or SDHD mutation accounts for at least $25 \%$ of type 2 GIST.

The mitochondrial complex 2 links the Krebs cycle and the electron transport chain and is illustrated below:

Published: 12 April 2012

\section{References}

1. van Nederveen FH, Gaal J, Favier J, et al: An immunohistochemical procedure to detect patients with paraganglioma and phaeochromocytoma with germline SDHB, SDHC or SDHD gene mutations: a retrospective and prospective analysis. Lancet Oncol 2009, 10:764-771.

2. Gill AJ, Benn DE, Chou A, Clarkson A, Muljono A, Meyer-Rochow G, Richardson A-L, Sidhu SB, Robinson BG, Clifton-Bligh RJ: Immunohistochemistry for SDHB triages genetic testing of SDHB, SDHC and SDHD in paraganglioma-phaeochromocytoma syndromes. Hum Pathol 2010, 41:805-814.

3. Gill AJ, Chou A, Vilain R, Clarkson A, Lui M, Jin R, Tobias V, Samra J, Goldstein D, Smith C, Sioson L, Parker N, Smith RC, Sywak M, Sidhu SB, Ma
C Biomed Central

๑ 2012 Gill; licensee BioMed Central Ltd. This is an Open Access article distributed under the terms of the Creative Commons Attribution License (http://creativecommons.org/licenses/by/2.0), which permits unrestricted use, distribution, and reproduction in any medium, provided the original work is properly cited. 
Table 1 Syndromes associated with paraganglioma and pheochromocytoma

\begin{tabular}{|c|c|c|c|}
\hline Syndrome & Gene & Incidence & Clinical syndrome \\
\hline Von Hippel-Lindau syndrome & VHL(3p25) & 1 in 36000 & $\begin{array}{l}\text { Retinal/CNS Hemangioblastoma } \\
\text { Conventional clear cell renal carcinoma } \\
\text { Phaeochromocytomas } \\
\text { Endolymphatic sac tumours } \\
\text { Pancreatic serous cystadenomas } \\
\text { Pancreatic neuroendocrine tumours } \\
\text { Epidymal/broad ligament papillary cystadenomas }\end{array}$ \\
\hline Multiple endocrine neoplasia type 2 & $\operatorname{RET}(10 \mathrm{q} 11.2)$ & 2.5 per 100000 & $\begin{array}{l}\text { Medullary thyroid carcinoma } \\
\text { Phaeochromocytomas } \\
\text { Parathyroid hyperplasia }\end{array}$ \\
\hline Neurofibromatosis type 1 & $\operatorname{NF1}(17 q 11.2)$ & 1 in 3000 & $\begin{array}{l}\text { Neurofibromas } \\
\text { Café au lait spors } \\
\text { Gliomas } \\
\text { Lisch Nodules }\end{array}$ \\
\hline Paraganglioma Syndrome type 1 (PGL1) & $\mathrm{SDHD}(11 \mathrm{q} 23)$ & $? ? ?$ & $\begin{array}{l}\text { Pheochromocytomas/Paragangliomas } \\
\text { Most common locations: } \\
\text { 1. Head and neck } \\
\text { 2. Adrenal } \\
\text { 3. Intraabdominal extra-adrenal } \\
\text { 4. Thorax } \\
\text { Type } 2 \text { GIST } \\
\text { Renal Tumors }\end{array}$ \\
\hline Paraganglioma Syndrome Type 2 & ??SDHAF2(11q13.1) & Extremely Rare & Head and neck paragangliomas \\
\hline Paraganglioma Syndrom Type 3 (PGL3) & $\operatorname{SDHC}(1 \mathrm{q} 21-23)$ & ??? (Rare) & $\begin{array}{l}\text { Head and neck paragangliomas } \\
\text { Renal tumours } \\
\text { Type } 2 \text { GIST }\end{array}$ \\
\hline Paraganglioma Syndrome Type 4 (PGL4) & $\mathrm{SDHB}(1 \mathrm{p} 35-36)$ & $? ? ?$ & $\begin{array}{l}\text { Pheochromocytomas/Paragangliomas } \\
\text { Increased risk of malignant behaviour } \\
\text { Most common locations: } \\
\text { 1. Intraabdominal extra-adrenal } \\
\text { 2. Adrenal } \\
\text { 3. Head and neck } \\
\text { 4. Thorax } \\
\text { Renal Tumours } \\
\text { Type } 2 \text { GIST }\end{array}$ \\
\hline Carney Triad & $\begin{array}{l}\text { No known familial case } \\
\text { No known mutation }\end{array}$ & Extremely rare & $\begin{array}{l}\text { 1.Paragagnlioma } \\
\text { 2. 'Type } 2 \text { Gist' } \\
\text { 3. Pulmonary chondroma } \\
\text { 4??Oesophageal leiomyoma?? } \\
\text { 5??Adrenal adenoma?? }\end{array}$ \\
\hline
\end{tabular}

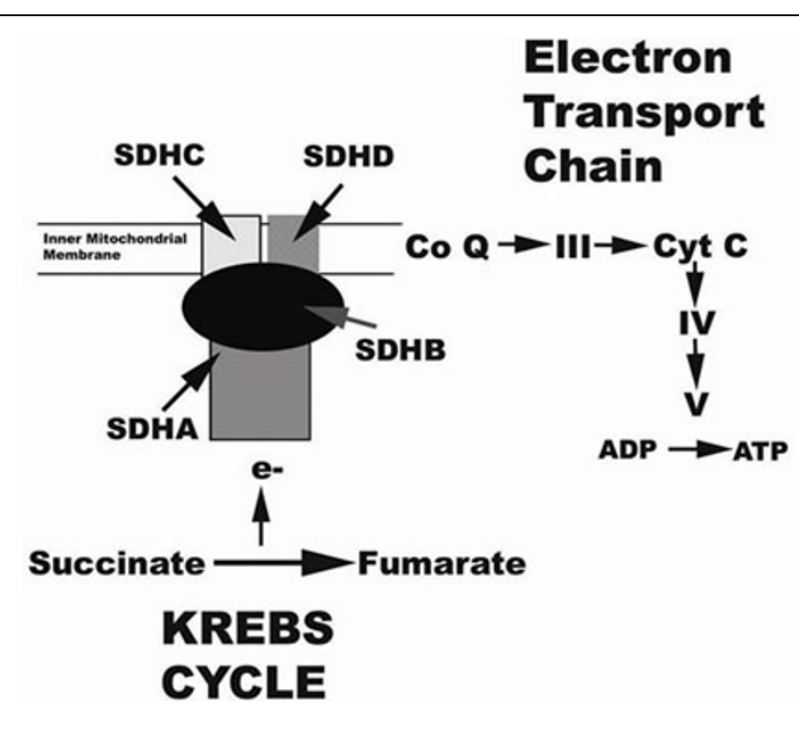

Figure 1 
Wyatt J, Robinson BG, Benn DE, Clifton-Bligh RJ: Immunohistochemistry for SDHB divides gastrointestinal stromal tumors (GISTs) into two distinct types. Am J Surg Pathol 2010, 34:636-44.

4. Gill AJ, Pachter NS, Clarkson A, Tucker KM, Winship I, Benn DE, Robinson BG, Clifton-Bligh R: Renal tumors and hereditary pheochromoytomaparaganglioma syndrome. N Engl J Med 2011, 364(9):885-886.

5. Gill AJ, Chou A, Vilain RE, Clifton-Bligh RJ: "Pediatric-type" gastrointestinal stromal tumors are SDHB negative ("type 2") GISTs. Am J Surg Pathol 2011, 35:1245-1247.

6. Gill AJ, Pachter NS, Chou A, Young B, Clarkson A, Tucker KM, Winship IM, Earls $\mathrm{P}$, Benn DE, Robinson BG, Fleming S, Clifton-Bligh RH: Renal tumors associated with germline SDHB mutation show distinctive morphology. Am J Surg Pathol 2011, 35:1578-1585.

doi:10.1186/1897-4287-10-S2-A7

Cite this article as: Gill: Use of SDHB immunohistochemistry to identify germline mutations of SDH genes. Hereditary Cancer in Clinical Practice 2012 10(Suppl 2):A7.

\section{Submit your next manuscript to BioMed Central} and take full advantage of:

- Convenient online submission

- Thorough peer review

- No space constraints or color figure charges

- Immediate publication on acceptance

- Inclusion in PubMed, CAS, Scopus and Google Scholar

- Research which is freely available for redistribution

Submit your manuscript at www.biomedcentral.com/submit 